\title{
Mocenské vztahy mezi začínajícími učiteli a jejich žáky ${ }^{1}$
}

\author{
Zuzana Šalamounová, Jarmila Bradová, Kateřina Lojdová \\ Masarykova univerzita, Pedagogická fakulta, Katedra pedagogiky
}

Redakci zasláno 10.1. 2014 / upravená verze obdržena 27. 5. 2014 /

k uveřejnění přijato 10. 6. 2014

\begin{abstract}
Abstrakt: Předložená teoretická studie se zabývá konceptem moci ve školní třídě. Jejím cílem je analyzovat koncept moci prostřednictvím jeho ústředních vlastností, a hlouběji tak porozumět jeho definici. V návaznosti na to poukazujeme na intervenující faktory, jež se do podoby mocenského uspořádání ve třídě promítají a které mohou zastávat významnou roli $\mathrm{v}$ mocenském uspořádání ve tř́dách začínajících učitelů a potažmo také studentů učitelství. V první části příspěvku je moc definována skrze tři její hlavní charakteristiky: cirkularitu, situačnost a reciprocitu. Druhá část příspěvku je věnována hlavním faktorům, které se do mocenského uspořádání ve školní třídě promítají. Těmito faktory jsou míra shody zájmů mezi učiteli a žáky, podoba vzájemných vztahů a kontext, v němž k uspořádání mocenských vztahů dochází. Z příspěvku vyplývá, že fenomén moci hraje u začínajících učitelů významnou roli. Právě u nich je totiž funkční nastavení mocenských vztahů vnímáno jako jeden z klíčových problémů při vstupu do profese a stává se také stěžejním důvodem pro její opuštění.
\end{abstract}

Klíčová slova: moc, konflikt, konsensus, kooperace, začínající učitelé, studenti učitelství, šok z reality

V předložené studii pojednáváme o jednom ze stěžejních konceptů sociálních, potažmo pedagogických věd, a to konceptu moci. Ústřední roli, kterou v procesu vyučování a učení zastává právě mocenské uspořádání, je dána tím, že sebekvalitnější učitelova znalost obsahu učiva zůstává bez tř́́dy s funkčně nastavenými mocenskými vztahy bez užitku (Kearney, Plax, Richmond, \& McCroskey, 1984). Edukační proces je za takových podmínek nemyslitelný, nebot' ve školních třídách nevzniká bezpečné učební prostředí, které by umožnilo optimální průběh celého učebního procesu (srov. např. Crone

1 Tento příspěvek vznikl s podporou projektu GAČR GA13-24456S Moc ve školních třídách studentů učitelství řešeného na katedře pedagogiky Pedagogické fakulty Masarykovy univerzity. Autorky děkují za poskytnutou podporu. 
\& Teddlie, 1995). Na vzájemnou spojitost mocenského uspořádání a edukačního procesu poukazuje také známá Bernsteinova teze (1996), podle níž ve škole dochází k prolínání dvou diskurzů, a to regulativního a didaktického. Zatímco regulativní diskurz definuje pravidla sociálního ch ování a vztahů ve škole, didaktický diskurz určuje, jaké znalosti budou žákům předávány. Podle Bernsteina (1996) je přitom regulativní diskurz didaktickému diskurzu vždy nadřazený, nebot’ určuje, jakým způsobem k procesu předávání znalostí dojde. ${ }^{2} \mathrm{~K}$ předávání didaktického obsahu tedy vždy dochází prostřednictvím uspořádání diskurzu regulativního, který podmiňuje diskurz didaktický (resp. je skrze něj projektován).

Cíle této teoretické studie ${ }^{3}$ vymezujeme dva. Za prvotní cíl si klademe analyzovat koncept moci prostřednictvím jeho ústředních vlastností, a hlouběji tak porozumět jeho definici. $V$ návaznosti na to chceme poukázat na intervenující faktory, jež se do podoby mocenského uspořádání ve třídě promítají a které mohou hrát významnou roli v mocenském uspořádání studentů učitelství, potažmo začínajících učitelů. Právě u nich je totiž funkční nastavení mocenských vztahů vnímáno jako jeden z klíčových problémů při vstupu do profese a stává se také stěžejním důvodem pro odchod z profese (Ingersoll, 1996; Veenman, 1987). Předtím než budeme o fenoménu moci hovořit, považujeme za nutné nastínit, proč se obracíme k užívání právě tohoto konceptu a jakým způsobem jej lze provázat s koncepty, které jsou v českém prostředí více zavedené.

\section{Koncept moci v českém pedagogickém prostředí}

V českém pedagogickém prostředí problematika moci jakožto koncept interaktivní povahy není příliš ukotvena a pozornost je průběžně věnována spíše příbuzným, dílčím a především unilaterálním konceptům. Setkáváme se tak s teoretickými pracemi, které problematiku vztahů mezi učiteli a žáky nahlížejí ze strany učitele a jeho působení a popisují jeho autoritu (Pařízek, 1988;

\footnotetext{
Sám Bernstein (1996) přitom dodává, že teoretické oddělení obou diskurzů je pouze schematické a v praxi nemožné, nebot' oba diskurzy jsou vždy realizovány současně.

3 V rámci prezentované teoretické analýzy jsme vedle klasických autorů věnujících se zkoumanému konceptu vycházeli z teoretických i empirických studií publikovaných v anglickém jazyce a zařazených do databáze Web of Science, mezi jejichž klíčovými slovy se nachází pojem moc a které jsou zařazeny do subdatabáze pedagogických věd. Na základě seznámení s texty jsme dále vybrali 32 studií, které se tematicky vztahují k problematice mocenského uspořádání mezi učiteli a žáky, resp. studenty. Je na místě uvést, že se jedná ve větší míře o studie vypovídající o anglosaském (americkém) kontextu.
} 
Vališová \& Kasíková, 2007) či autoritativnost (Čáp \& Mareš, 2007), nebo ze strany žáků a jejich chování (např jejich kázeň a zejména nekázeň, Bendl, 2001, případně disciplína, srov. Malach, 2007; k problematice kázně se vracíme v kapitole 3.1 tohoto textu), a to bez jednoznačného terminologického vymezení. Výjimku z teoretických prací tvoří zejména práce pražské skupiny školní etnografie, mezi nimiž můžeme jmenovat např. př́spěvek Viktorové (1995) vypovídající o autoritě v kontextu př́pravy na profesi učitele, na druhé straně pak dotazníkové šetření Novotného (1997) zabývající se autoritářstvím učitele. Domníváme se, že právě převládající nazírání na autoritu či autoritativnost jakožto vlastnost či dispozici učitele vede $\mathrm{k}$ tomu, že posesivita je analogicky, leč mylně promítána také do uvažování o konceptu moci.

Přímo s konceptem moci se setkáváme taktéž, avšak spíše sporadicky např. v metodických pracích Vališové (1998), která jej nicméně chápe synonymně s pojmem autorita, nebo u Maňáka (2003), který však moci přisuzuje primárně negativní konotace. S empirickým uchopením fenoménu (v jeho neutrálním pojetí, ve shodě se zahraniční literaturou) se setkáváme ojediněle, např́klad v empirické stati Kučery (1995), který o moci hyperbolicky hovoří jako o možnosti někomu něco vnucovat (což nemusí být chápáno negativně, může jít o dobré rady a poznatky), ve studiích Makovské pojednávajících o zobrazení moci v žákovských příbězích (2010) a žákovských technikách změny chování (2011) a zejména ve studiích Šed'ové $(2011,2012)$, která mocenské vztahy dává do souvislosti se strukturováním výukové komunikace a definuje čtyři mody tzv. mocenských konstelací. $Z$ důvodu poměrně krátké historie tohoto konceptu $\mathrm{v}$ českém pedagogickém prostředí jsme se proto v prvním kroku zaměřily na jeho definici. Z analýzy literatury, jež se tomuto konceptu věnuje, přitom vzešly tři jeho stěžejní charakteristiky, které popisujeme dále.

\section{Moc na průsečíku cirkularity, situačnosti s reciprocity}

\subsection{Cirkularita moci}

Cirkularita moci předznamenává, že moc je ve školních třídách všudypřítomná a nepřetržitě se pohybuje mezi učitelem a žáky i žáky navzájem. Moc se ze třídy nikdy neztrácí. Spíše než aby však byla někým konstantně vlastněna, od situace k situaci cirkuluje po třídě (Buzzelli \& Johnston, 2001, s. 875). Když tedy např́klad učitelé hovoří o ztrátě kontroly, neznamená to, že by se moc ze třídy vytrácela a mizela, ale že se modifikuje takovým způsobem, že mohou navrch získávat žáci (Aultman, William-Johnson, \& Schutz, 2009, s. 364). 
Obdobné uspořádání přitom nelze automaticky nahlížet jako nefunkční. Tuto skutečnost vhodně ilustruje Winograd (2002), který uvádí situaci, kdy svým žákům na prvním stupni řekl, že až úspěšně vypočítají řešení dvou matematických př́kladů, mohou si kreslit. Ve chvíli, kdy do konce hodiny zbývalo pouze několik minut a většina žáků si již v lavici hrála, přišla za ním žákyně, která byla na matematiku nejslabší, přinesla mu sešit $\mathrm{s}$ jedním správně vyřešením př́íkladem a zeptala se, zda by si taktéž mohla chvíli kreslit. Vzhledem k tomu, že autor věděl, že v rámci svých možností odvedla žákyně více práce, než dalo řadě jejích spolužáků vypočítat příklady oba dva, ustoupil jejím požadavkům, čímž bylo jeho původní zadání modifikováno. Uspořádání vyučovací situace tak, že rozhodovací pravomoci jsou sdíleny, tedy pro učitele neznamená cíleně abdikovat (Schulz \& Oyler, 2006).

Tuto vlastnost moci pravděpodobně nejvýstižněji charakterizuje Foucault (1978, s. 2; podobně také Oyler, 1996): „Moc není pevná komodita, kterou někdo vlastní, může ji rozdělit jako koláč a sdílet, ale je to volně plovoucí, rozptýlená a produktivní síla, která tvaruje nás samotné i naše vztahy. $\mathrm{S}$ tímto vědomím již nemáme mocné učitele a bezmocné žáky, ale mnohočetné, všudypřítomné mocenské vztahy, které nás zmocňují a omezují ve stejnou chvíli." Pokud ve školní třídě učitel přispěje ke změně uspořádání mocenských vztahů tak, aby do nich mohli více intervenovat žáci, nemusí to pouze automaticky znamenat, že pozice učitele je tím oslabena. Sdílením moci se žáky může být pozice učitele naopak upevněna. Představa distribuce moci ve trrídě tedy neodpovídá podobě vah, kde jedna miska stoupá na úkor druhé.

\subsection{Situačnost moci}

S cirkularitou moci úzce souvisí její situačnost, z níž vyplývá, že uspořádání mocenských vztahů se neustále proměňuje napříč situacemi a jejich jednotlivými rovinami (Jacobs, 2012; Hawes Denos, 2003). V rámci jedné vyučovací hodiny tak dochází k opakovanému (re)konstruování mocenského uspořádání mezi učiteli a žáky (jako jednotlivci i jako skupinou) napříč jednotlivými situacemi a aktivitami, v prostorovém kontextu školní třídy a politicko-ekonomickém kontextu učitelů a školní lokality (Winograd, 2002, s. 344). Přestože učitelé se svými žáky často dospívají k jednomu typu uspořádání, který může být pro jejich vztah určující (srov. vymezené mocenské konstelace Šed'ové, 2011, 2012), neznamená to, že by se celá vyučovací hodina odehrávala právě v tomto modu. 
V souvislosti s mocí jakožto situačním fenoménem můžeme ilustrovat, proč moc nelze vymezit unilaterálně a chápat ji jako vlastnost jednotlivce. Pokud by totiž moc byla vlastností jednotlivce či skupiny, nebylo by možné, aby docházelo k modifikaci mocenských vztahů např́iklad vlivem změny prostoru. Namísto toho by existovala pouze fixní struktura vzájemných pravidel. Tomu však odporuje např́́klad výzkum Kenkmannové (2011), který dokládá, jak může mocenské uspořádání proměnit například změna prostoru, v němž se výuka odehrává. Autorka na základě svého empirického šetření dokazuje, že ve chvíli, kdy se vysokoškolská výuka přesune do prostoru muzea, dochází také ke změnám v mocenském uspořádání. Zatímco učitel byl ve výzkumu autorky doposud ten, kdo byl ve výukovém prostoru „doma“, vítal studenty ${ }^{4}$ v prostoru učebny a zasahoval do toho, co se bude ve které její části odehrávat, v muzeu dochází ke společnému vytváření výukového prostoru, nebot' všichni přichází zvnějšku jakožto cizí. V důsledku toho dochází $\mathrm{k}$ hledání nových teritorií i prostoru pro společnou i individuální práci, novému ustavování pravidel a dočasných norem.

Uvažování o roli fyzického prostoru školní třídy v kontextu mocenského uspořádání mezi učitelem a žáky se opírá o tradičníjména, přičemž není nutné chodit až do muzea. Jak nastiňuje Goffman (1999), spojení mezi prostorem a mocí se objevuje již dlouho, což platí také ve školní třídě. Již tím, kde učitel stojí, zaujímá určité mocenské postavení, nebot' tím určuje, ke komu mluví, na koho se dívá apod. (srov. Bradová, 2013). To rezonuje s Foucaultovou tezí (1978), že využití prostoru není nikdy neutrální.

Situačnost moci pochopitelně nesouvisí pouze s uspořádáním výukového prostoru a rozestavěním jednotlivých aktérů v něm. Stejně tak je patrná v závislosti s tím, jak se mocenské uspořádání proměňuje $\mathrm{v}$ závislosti na aktivitě, která ve třídě probíhá, fázi hodiny (srov. Winograd, 2002), jejím zařazení v rozvrhu, dobou ve školním roce atd.

\subsection{Reciprocita moci}

Do třetice koncept moci definujeme ve smyslu recipročního vztahu, v jehož rámci dochází ke vzájemnému ovlivňování postojů, hodnot a jednání (srov. např. McCroskey, Richmond, \& McCroskey, 2006; Moscovici, 2007). K tomuto

4 Označení studenti je systematicky používáno pro studenty vysokých škol či univerzit. V př́ípadě, kdy pojednáváme o prostředí základních či středních škol, pak vždy hovoříme o žácích. 
procesu přitom nedochází na základě toho, že jedna ze zúčastněných stran disponuje určitými zdroji, na jejichž základě může ovlivňovat druhou ze zúčastněných stran, ale tím, že je takto vnímána. Přestože se tedy poměrně často hovoří např́íklad o moci učitele, nejedná se o jeho dispozici, jak by mohlo z daného sousloví mylně vyplývat, ale o percepci ze strany toho, kdo s ním vstupuje do vztahu, např́íklad žáků nebo rodičů. Na tomto principu jsou vystavěna také nejrůznější dotazníková šetření, která moc učitele měří (srov. Elias, 2007; French \& Raven, 1959; Schrodt, Witt, \& Turman, 2007). Pokud si tuto relaci ukážeme na př́kladu legitimní moci (moci přisouzené na základě sociální role učitele), znamená to, že zkoumáme nikoli to, nakolik učitelé nedisponují legitimní mocí, ale do jaké míry mají jejich žáci zvnitřnělé hodnoty, které jim diktují, že učitelé mají legitimní právo dávat žákům určité instrukce (srov. Jamieson \& Thomas, 1974). K vymezení moci proto přistupujeme ve smyslu působení v rámci recipročního vztahu (srov. Goffman, 1959; Woods, 1983, Kaščák, 2006) či „silového pole“ (Kaščák, 2008, s. 128), z interakcionalistické perspektivy (Staton, 1992).

Z reciprocity moci vyplývá, že pro porozumění mocenským vztahům je nutné porozumět tomu, jak situaci vnímají všechny zúčastněné strany. Ve školní třídě přitom můžeme mocenské vztahy identifikovat např́íc třemi úrovněmi - mezi žáky a učiteli, mezi žáky navzájem a také mezi učiteli a žáky a školou jakožto institucí (Jacobs, 2012). Ani při zúžené optice, kdy dochází ke zkoumání pouze jedné z nastíněných úrovní, přitom nelze zcela opomenout ostatní úrovně, na kterých se mocenské vztahy utvářejí a modifikují.

\subsection{Definice moci}

Moc ve školní třídě můžeme na základě teoretické analýzy definovat jako kontextově vázané uspořádání, $v$ jehož rámci učitel i žáci (jakožto jednotlivci i skupina) vzájemně ovlivňují své postoje, hodnoty a jednání. Na základě cirkularity moci můžeme sledovat, jak se podoba mocenského uspořádání modifikuje mezi učitelem a kolektivem žáků, mezi učitelem a jednotlivými žáky i mezi žáky navzájem. K tomuto ovlivňování přitom dochází v závislosti na tom, jakým způsobem do mocenského uspořádání jednotliví aktéři intervenují a jak jsou v danou chvíli vnímáni ostatními (v čemž spočívá podstata reciprocity moci). $\mathrm{V}$ obou těchto bodech můžeme hovořit o vertikální modifikaci mocenského uspořádání. Situačnost moci pak přispívá $\mathrm{k}$ tomu, že se uspořádání mění $\mathrm{v}$ čase (dochází $\mathrm{k}$ horizontální modifikaci), v závislosti na jednotlivých mikrosituacích světa školní třídy a jeho okolí. 


\section{Co vstupuje do mocenského uspořádání mezi učiteli na začátku profesní dráhy a jejich žáky}

V předcházejícím textu jsme naznačily, že do podoby mocenského upořádání ve školní tř́dě se promítá celá řada intervenujících faktorů. $V$ této studii se však budeme věnovat pouze těm, které jako červená nit prostupují napříč zahraničními studiemi a jež lze považovat za ty nejzásadnější, resp. nejčastěji zmiňované a empiricky zkoumané. Nejedná se o výčet, který by si činil nárok na úplnost. Poukazujeme přitom na faktory, které souvisejí s potenciálními specifiky mocenského uspořádání ve tř́dách začínajících učitelů či studentů učitelství.

\subsection{Mezi střetem zájmů a konsensem}

Aktuální podoba mocenského uspořádání ve školní třídě se v první řadě odvíjí od zájmů, jež učitelé a žáci mají a kterých by v prostředí školní třídy chtěli dosáhnout. Učitelé i žáci přicházejí do školy s určitými snahami, zájmy a cíli, z nichž některé mohou sdílet, ale jiné mohou být zcela odlišné povahy. Holt (1964, in Moscovici, 2002) v tomto kontextu hovoří o definici situace z pohledu jednotlivých aktérů. Stejný termín v českém prostředí induktivně volí také Šed'ová $(2011,2012)$, která detailně poukazuje na to, jak se do mocenského uspořádání mezi učitelem a žáky promítá, zda sdílejí definici situace a akceptují totožné cíle, nebo situaci definují odlišně.

Jak konstatují Cothranová a Ennisová (1997), zatímco učitelé sledují především cíle vzdělávací, žáci a studenti si cení především cílů sociálních. To se projevuje např́klad frekventovanou kontrapozicí my vs. oni v rozhovorech s učiteli i žáky (což autorky dokládají na svém šetření z prostředí střední školy). Mezi prríčiny, které vedou učitele i žáky k prosazování různých zájmů, řadí Hammersley a Woods (1984) mimo jiné také odlišné strukturování cílů v čase, který ve škole stráví. Zatímco učitelé totiž své cíle vnímají jako dlouhou cestu, po níž žáky doprovází, a své cíle tak strukturují dokonce v horizontu let, žáci své cíle vnímají a nastavují v mnohem kratších časových úsecích, $\mathrm{z}$ hodiny na hodinu, ze dne na den. Toto odlišné vnímání cílů v čase ilustruje Winograd (2002, s. 345) na př́kladu učitele francouzštiny, který si představuje, jak studentům na konci studia zprostředkuje nejen jazyk, ale jeho prostřednictvím také francouzské umění a historii, zatímco jeho žáci chtějí přežít hodinu a zvládnout test. Odlišnost cílů dále vyplývá z toho, že pro žáky jsou nejvýznamnější ty aktivity, které reflektují jejich kulturu (Woods, 1984, 
s. 234), avšak při práci s učivem ve škole zpravidla dochází k dekontextualizaci ${ }^{5}$ (Cazden, 1988; Makovská, 2011), určitému abstraktnímu zobecňujícímu oddálení od konkrétních zkušeností předávané odosobněným jazykem školy (srov. Forman, McCormick, \& Donato, 1998, s. 315).

Pokud přitom učitelé a žáci vnímají cíle situace zcela odlišně, je uspořádání problematické a mocenské uspořádání přispívá ke konfliktu, který je v důsledcích ohrožující pro všechny zúčastněné (Viktorová, 1995, s. 104). Alespoň částečná shoda na směřování situace a jejích cílech je totiž podmínkou procesů vyučování a učení (Ingersoll, 1996, s. 164). Jak podotýká Sedlak se spoluautory (1986, in Cothran \& Ennis, 1997, s. 543), pokud se uspořádání mezi učiteli a žáky promění $v$ dlouhodobější bitvu o to, jak vyřešit konflikty zájmů, stane se tř́da místem viditelného, rušivého nepořádku. Edukační proces je pak za takovýchto podmínek nemyslitelný, nebot' ve školních třídách nevzniká bezpečné učební prostředí, které umožňuje maximalizovat intelektuální i osobní potenciál žáků. Na základě empirických důkazů lze konstatovat, že úměrně s poklesem funkčního uspořádání učebního prostředí ve třídě klesají také učební výsledky, kterých žáci dosahují (Marzano, Marzano, \& Pickering, 2003; Stage \& Quiroz, 1997).

Některé z cílů jsou však pro učitele a žáky společné, což Cothranová a Ennisová (1997, s. 550) ilustrují výpovědí jedné ze svých středoškolských respondentek: „Učitelé si chtějí být jistí, že dobře odmaturuješ, zatímco žáci chtějí mít zábavu. Všichni ale chtějí, abychom nějak prošli." Podle Lortieho (1975) mají učitelé i žáci dva hlavní cíle - pro učitele je to cíl mít spořádanou třídu a vést žáky $\mathrm{k}$ učení, zatímco pro žáky je to členství ve vrstevnické skupině a mentální stimulace (srov. také Winograd, 2002). Také zde tedy můžeme sledovat potenciální překrývání zájmů učitelů a žáků. Pokud se výuka pro žáky stane mentální stimulací, dochází k prolnutí jejich zájmů se zájmem učitelů a dochází ke konsensu, ideálně ke kooperaci.

Například Hargreaves (1972) však podotýká, že shody v cílech je dosaženo pouze ojediněle (srov. také Goffman, 1959). Ke stejnému závěru na základě svého empirického šetření u učitelů a žáků středních škol dospěl také Winograd (2002), který poznamenává, že pojetí v tom smyslu, že mezi učiteli

5 Janík, Slavík a Mužík et al. (2013, s. 202) hovoří o dekontextualizaci také jako o způsobu, který umožňuje žákovi „uskutečnit cestu do vlastní kultury, protože mu poskytuje nástroje, jejichž platnost přesahuje jeho nejbližší prostředí, místo a čas". Učení ve škole podle autorů obecně směřuje k dekontextualizaci. 
a žáky se jedná především o vztah založený na spolupráci, kde se obě strany snaží, aby uspokojily potřeby druhé strany, je romantizující vize. Učitelé i žáci si však jsou vědomi toho, že disponují tím, po čem druhá strana touží, a v důsledku mohou ovlivnit podobu výuky. Tento „směnný obchod“ vhodně popisují Cothranová a Ennisová (1997, s. 550) - žáci vědí, že učitelé chtějí, aby $\mathrm{s}$ nimi žáci ve výuce spolupracovali. Učitelé si na druhou stranu jsou vědomi toho, že žáci chtějí dobré známky, nebo alespoň takové, aby mohli ve studiu pokračovat. Mohou tedy navzájem vyjednávat, čímž dochází k vyjednávání různých typů kompromisů, a chovat se kooperativně, a to i navzdory skrytému střetu zájmů (srov. Jamieson \& Thomas, 1974).

Podoby kompromisů podrobněji popisuje Hargreaves (1972), který hovoří o tzv. pseudoshodě, tzv. pracovním konsensu, který má tři podoby. Prvním typem pseudodohody je kompromis, $v$ jehož rámci se sice nevyřeší, že učitelé a žáci mají rozdílné cíle, ale obě strany udělají určité ústupky. Druhým typem je hegemonie, kdy si učitel ve chvíli rozdílných cílů prosadí ty své a větši ústupky nastanou ze strany žáků (dochází k tzv. žákovské akomodaci, srov. Jamieson \& Thomas, 1974). Učitelé pak v těchto situacích volí aktivity, které maximalizují vyhovění žáků a minimalizují jejich resistenci, uchylují se k donucování či manipulaci (Cothran \& Ennis, 1997, s. 550). Posledním typem pak je kontra-hegemonie (Hargreaves, 1972), kdy se situace odvíjí podle cílů žáků a dochází $\mathrm{k}$ akomodaci učitele. Učitelé přitom ve chvíli, kdy mocenské uspořádání ve tř́́dě ústí v kontra-hegemonii, mohou volit postup strategického stáhnutí se, kdy místy až rezignují na předávání znalostí a dělají to, co žáky zabaví (Cothran \& Ennis, 1997, s. 549). Podle Hargreavse (1972) učitelé při uspořádání v podobě kontra-hegemonie často používají strategii, kdy vystupují, jako by žákủm záměrně udíleli privilegium. Touto cestou se tak učitelé snaží kontra-hegemonii maskovat, jako by se jednalo o konsensus. Ve chvíli, kdy by totiž učitelé anti-hegemonii nemaskovali a vystupovali by proti ní dominantně, došlo by ke kompetici mezi učitelem a žáky, čímž by mohla vystoupit míra konfliktů ve třídě (Jamieson \& Thomas, 1974, s. 542).

Pokud se na tato uspořádání podíváme optikou uvažování o žákovské kázni, vidíme zásadní deficit tohoto konceptu. Kázeň ve smyslu „vědomé(ho) dodržování zadaných norem chování“ a „vědomé(ho) podřízení se zadaným normám“ (Bendl, 2004, s. 23) totiž nemá vypovídající hodnotu ohledně míry kooperace ve trrídě. Žáci mohou být ukáznění jak při kooperaci, tak např́íklad při různých typech hegemonie. Mezi nejfrekventovanější projevy nekázně je naopak řazeno vykřikování žáků bez vyzvání učitelem (srov. Merrett \& Whelldal, 1993), které však lze vnímat jako indikátor žákovské angažova- 
nosti ve třídě nastavené v modu kooperace. Mohly bychom proto dokonce uvažovat nad tím, zda při hegemonii nebude třída působit ukázněněji než při kooperaci, nebot' uspořádání založená na cirkulaci moci mezi učitelem a žáky jsou charakteristická vyšší mírou šumu ve tř́́dě (srov. Šed'ová, 2011). Přesto bude zapojení žáků a jejich motivace vyplývající ze sledování zájmů, s nimiž se ztotožňují, zcela odlišná.

\subsection{Interpersonální vztahy mezi učiteli a žáky}

Spolu s tím, jakým způsobem učitel i jednotliví žáci definují své cíle, které si kladou od pobytu ve školní třídě, vstupují do podoby mocenského uspořádání také interpersonální vztahy, které mezi sebou učitel a žáci mají. Jak podotýká Aultmanová s kolegyněmi (2009, s. 363), emoce mezi učiteli a žáky souvisejí s tím, co obě strany považují ve trrídě za přijatelné a co nikoli, což se př́mo prolíná s problematikou moci. Právě povaha interpersonálního vztahu mezi učiteli a žáky pak souvisí s tím, $v$ jaké míře se učitelé i žáci ve třídě dostávají do konfliktu, nebo se naopak rozhodují pro vyhovění požadavkům druhé strany (srov. Murray \& Pianta, 2007), čímž vzniká jasná spojnice mezi uspořádáními, které jsme představily výše, a podobou interpersonálních vztahů ve tř́ldě.

Mocenské uspořádání a podobu interpersonálních vztahů mezi jinými dlouhodobě propojuje například Wubbels (srov. např. Wubbels \& Brekelmans, 2005), který v modelu interpersonálního chování učitele (Wubbels, Creton, \& Hoomayer, 1992) propojuje chování účastníků interakce (učitele a žáků) a míru kontroly těchto interakcí. Kontrolu interakce, která značí, kdo z interagujících její průběh ovlivňuje, Wubbels vymezuje v poli od dominance k submisivitě, chování účastníků v závislosti na blízkosti mezi učitelem a žáky diferencuje od opozice ke kooperaci ve třídě. Pokud tento model propojíme s předcházejícím vymezením definice situace, můžeme říci, že dominantní učitel předdefinovává žákovské aktivity, čímž se blíží uspořádání v podobě hegemonie či kooperace, v níž žáci ochotně následují zájmy učitele, zatímco submisivní učitel v případě žákovské převahy své žáky nechává, aby oni sami řídili své aktivity, čímž třídu staví do modu kontra-hegemonie, prrípadně dochází k nastavení kooperace s podřízením se ze strany učitele. Tomu odpovídají také mocenské konstelace Šed'ové $(2011,2012)$. U dominantního učitele, v jehož tř́iě se vztahy přibližují kooperaci, nastává uspořádání v modu tzv. zobání z ruky, kdy žáci s učitelem kooperují, nebot’ mu sami chtějí vyhovět. Ve směru od kooperace $\mathrm{k}$ opozici se třída přesouvá do modu tzv. přesilov- 
ky, kdy jsou taktéž realizovány zájmy učitele, který si je bez ohledu na zájmy žáků dokáže prosadit. Submisivní učitel ve tř́dě s blízkými vzájemnými vztahy otevírá možnost uspořádání v podobě tzv. cirkulace moci, kdy dochází k rovnocennému zohledňování zájmů obou stran. Ve chvíli, kdy se však submisivní učitel ocitne ve třídě, kde s žáky nemá vybudované kvalitní mezilidské vztahy, dostává se třída do modu tahanice, konfliktní přetahované mezi oběma stranami. Vidíme tedy, že do podoby mocenského uspořádání se výrazně promítá, jaký mezi sebou mají učitelé a žáci vztah, což může ovlivňovat také to, jakým způsobem obě strany vnímají výukovou situaci a její cíle.

Uspořádání založené na konsensu a kooperaci je přitom typické pro tř́dy, v nichž je mezi učiteli a žáky přátelský vztah či vztah založený na vzájemném porozumění. Jak opakovaně zaznívá $\mathrm{z}$ výzkumných šetření, kooperace mohou snáze dosáhnout učitelé, kteří jsou ze strany žáků oblíbení. Pokud je učitel žáky viděn jako zábavný, zajímavý a osobitý, často se zapojuje do žákovských či studentských aktivit, používá ve třídě humor apod. (Alderman \& Green, 2011), žáci se s ním cítí více propojeni, čímž může snáze dojít ke sdílení definice situace. Na vysokých školách je $v$ rámci prátelského vztahu např́íklad důležité, aby vyučující znal alespoň jména svých studentů (viz Hilsdon, 1997). Kvalitní vztahy mezi učiteli a jejich žáky či studenty proto není snadné vytvořit a udržet, nebot' vyžadují emoční investice (Aultman et al., 2009, s. 364).

Interpersonální vztahy úzce souvisí také s vývojem kariérní dráhy učitele. To prokazuje např́klad Moscovici (2007; srov. také Lukas, 2007), který popisuje, že na začátku své profesní dráhy se učitelé snaží být spíše kritickými přáteli svých žáků, zatímco postupem času mohou být vnímáni spíš jako př́liš nároční „čarodějníci“, což se pochopitelně promítá do podoby vzájemných vztahů, a tím také do podoby mocenského uspořádání ve tř́íě. Také další autoři (Aultman et al., 2009, s. 364; Viktorová, 1995, s. 108) potvrzují, že studenti učitelství a mladší učitelé více než jejich starší kolegové stojí o to, aby je jejich žáci měli rádi a aby s nimi dosáhli přátelského vztahu. Pilotní šetření, jež v českém prostředí realizovaly Vlčková, Bradová a Šalamounová (2013) a které se zaměřovalo na to, jak žáci vnímají své učitele v závislosti na jejich věku, přitom vychází vstříc tomuto přání učitelů na prahu, případně s kratší délkou praxe. S učiteli s kratší délkou praxe totiž žáci druhého stupně základní školy mají pozitivnější vztah než s učiteli, kteří se již ve školství pohybují delší dobu. 
Žádnou roli ve vztahu k interpersonálním vztahům ve tř́dě naopak nehraje gender učitele. Jak poukazují např́klad Eliasová a Mace (2005) v závislosti na realizovaném dotazníkovém šetření mezi studenty vysokých škol, studenti vnímají učitelské intervence do mocenského uspořádání stejným způsobem, a to at' se jedná o muže učitele, nebo ženy učitelky.

Do podoby vzájemných vztahů samozřejmě vstupují také charakteristiky žáků či studentů a jejich skladba ve tř́dě. Cothranová a Ennisová (1997, s. 542) v americkém kontextu hovoří například o změnách ve vnímání univerzitního učitele vzniklých z narůstající diverzity studentů. Studenti, kteří nevycházejí z euroamerického kulturního prostředí, totiž nepřistupují na to, že by učitele automaticky měli vnímat jakožto někoho, kdo disponuje mocí. 0 individuálních charakteristikách a specifických požadavcích žákư základních škol ve vztahu k učiteli pak vypovídá např́íklad Winograd (2002), který konstatuje, že k mocenskému vyjednávání častěji dochází u dětí se specifickými vzdělávacími potřebami, nebot' ty nejčastěji potřebují, aby se jim výuka v určitém ohledu přizpůsobila.

\subsection{Svět za hranicemi školní třídy}

V souvislosti se základními atributy fenoménu moci jsme uvedly, že mocenské uspořádání závisí na kontextu, do něhož je zasazeno. Pokud tedy chceme uvažovat o mocenském uspořádání ve školní třídě, měly bychom vzít v potaz také sociokulturní a historický makrokontext a kontext školy.

Základním prvkem sociokulturního kontextu, který se zřetelně promítá do mocenských uspořádání ve třídách, je samotný fakt, že školní docházka je povinná. Žáci jsou proto nedobrovolnými návštěvníky škol a místní agenda pro ně často není př́liš zajímavá (Winograd, 2002). Historickou perspektivu do tohoto uvažování vnáší Foucault (1978, s. 344), který argumentuje, že mocenské uspořádání je vždy prezentováno řadou instrumentů, kam spadají např́klad aktuální vzdělávací dokumenty a programy, strategické dokumenty a nástroje. Foucault (1978) dále hovoří také o tzv. strukturální limitaci, která vymezuje, co je ve třídě možné a co již nikoli. Strukturální limitace tedy ustavuje např́iklad nepř́ípustnost určitých trestů a hrozeb ve třídě (Winograd, 2002, s. 345; přehled v českém prostředí přináší např. Rigel, 2012).

Dalším podstatným faktorem je proměna toho, jak je celospolečensky nahlížena role učitele. Tomuto tématu se v americkém kontextu věnuje Ennisová (1995), která podotýká, že pozice učitele donedávna, bez ohledu na osob- 
nostní charakteristiky, získávala respekt, což již dnes neplatí. Respektování role učitele (a tím percipovaná legitimní moc vyplývající z této role) například na středních školách bylo dříve dáno také hodnotou středoškolského diplomu, který žáci získávali. Dnes však úspěch ve škole negarantuje ekonomickou úspěšnost po absolvování studia (srov. Keller \& Tvrdý, 2008), takže učitelé mají menší vliv na život svých žáků (Cothran \& Ennis, 1997). S tím, jak je vnímána pozice učitele, souvisí také lokalita a region, v nichž se škola nachází (Oyler, 1996; Elias \& Mace, 2005), a předpokládané studijní aspirace studentů (Oyler, 1996).

Na úrovni školy jakožto instituce se v zahraniční literatuře uvažuje zejména o vztazích mezi učiteli a žáky a dalšími aktéry života školy. Pozornost se přitom hojně věnuje vztahu učitelů a vedení školy. S oporou o šetření Cothranové a Ennisové (1997, s. 548) lze např́klad říci, že učitelé sebe sama vnímají jako více schopné zasáhnout do mocenského nastavení ve tř́́dě ve chvíli, kdy se cítí podpořeni vedením. Učitelé v tomto výzkumu však vypovídají o dominantním nezájmu ze strany vedení školy, v důsledku čehož necítí podporu své práce. Dalším faktorem, který se ve svém důsledku promítá také do mocenského uspořádání ve školní třídě, je míra autonomie učitele v souvislosti se vzdělávacími procesy ve tř́́dě. Na základě reprezentativního dotazníkového šetření udává například Ingersoll (1996, s. 169), že čím větší je míra autonomie učitele ohledně dění ve třídě, tím nižší je míra konfliktů, k nimž ve třídě mezi učitelem a žáky dochází. Učitelé by přitom ideálně neměli mít autonomii a pravomoci pouze na úrovni tř́dy (např. ve výběru učebnic, témat, materiálů, výukových postupů), ale také na úrovni školské politiky své instituce. Posledním faktorem na úrovni školy, který v návaznosti na zahraniční šetření zmíníme, je vztah učitelů a rodičů jejich žáků. Jak v této souvislosti podotýká Winograd (2002, s. 359), absentující podpora rodičů se do mocenského uspořádání ve třídě silně promítá, a není nic, co by je mohlo narušit více než „rodičovský cynismus vztahující se ke škole“.

\section{Závěrem aneb $\mathrm{K}$ mocenskému uspořádání ve třídách budoucích učitelů}

Výzkumná šetření dokládají (Richmond \& Roach, 1992; Staton, 1992; Švaříček, 2007, s. 313), že mocenské uspořádání ve třídách začínajících učitelů či studentů, kteří stojí před vstupem do profese, bývá často problematické. Učitelé po skončení profesní přípravy, na začátku své kariérní dráhy, totiž mnohdy nevědí, jak adekvátně dostát požadavkům na ustavování moci 
ve svých tř́idách. K tomu, že nastavení funkčního uspořádání ve tř́ídě je problém především začínajících učitelů, dospěl na základě metaanalýzy výsledků 95 studií z USA a Evropy Veenman (1987), jenž hovoří o tzv. šoku z reality, který mladé učitele po nástupu do profese zasáhne. Tento šok charakterizuje zborcením ideálů z univerzitních auditorií, $\mathrm{k}$ němuž dochází v kontaktu s realitou školních tříd (v českém prostředí se ke stejnému označení uchyluje napřs Švaříček, 2009, s. 151). S tímto stanoviskem souhlasí také Kremer-Hayon a Ben-Peretz (1986), kteří ve své studii týkající se překážek, s nimiž se začínající učitelé v počátcích své praxe setkávají, zdůrazňují právě šok z reality - moment, kdy si mladí učitelé uvědomí, že skutečná edukační realita je diametrálně odlišná od jejich původních představ o učitelství. Výzkum z devadesátých let ukazuje, že 40 \% začínajících učitelů nevydrží ve své zvolené profesi déle než čtyři roky, přičemž polovina z tohoto počtu opustí své povolání do tř́ let (Bernshausen \& Cunningham, 2001).

S oporou o dosavadní text se nyní podívejme na to, proč může být právě mocenské uspořádání ve třídách potenciální Achillovou patou začínajících učitelů i studentů učitelství. Jako první z důvodů můžeme uvést problém s definováním cílů a dosahováním shody na těchto cílech mezi učitelem a žáky. Z výzkumu Winograda (2002) v této souvislosti vyplývá, že začínající učitelé stejně jako studenti učitelství v důsledku své nezkušenosti mnohdy nemají jasnou vizi toho, čeho by ve školní tř́idě chtěli dosáhnout. K podobným závěrům v českém prostředí dospěl také Švaříček (2009, s. 151-159), který při biografickém výzkumu životní dráhy učitelů expertů konstatoval, že učitelé v počátečních fázích působení (na základě své žákovské a studentské zkušenosti, srov. Pravdová, 2013, s. 189) ve své nové roli sice vědí, co ve své vlastní praxi konat nechtějí, avšak nemají zcela jasno v tom, co vykovávat chtějí. V takové situaci je pak obtížné dosáhnout s nimi shody na definici situace, nebot' jejich vlastní situace je zkrátka nedefinovaná. Začínající učitelé navíc doposud mnohdy nejsou ztotožněni se svou rolí učitelů a stále sebe sama vnímají spíše „na druhé straně“ (Lukas \& Švaříček, 2007, s. 5-6). Všechny tyto důvody vedou k tomu, že začínající učitelé i studenti učitelství mohou být $\mathrm{z}$ hlediska definování cílů nejistí, a tím z pohledu svých žáků nečitelní, $\mathrm{v}$ důsledku čehož je snadné dojít ke konfliktnímu uspořádání. Winograd (2002, s. 360) z této zkušenosti u svých studentů učitelství usuzuje, že je zásadní s nimi pracovat na definování jasných a ze strany žáků dekódovatelných cílů a hledání způsobů, jak těchto cílů dosáhnout, což vnímá jako silný impulz pro učitelskou př́pravu. 
Definování cílů úzce souvisí se schopností př́ípravy funkčního plánu hodiny. Učitelé na startu své profesní dráhy sice zpravidla disponují kvalitními znalostmi oborového obsahu, nicméně mohou mít problémy s tím, které z nich v hodině předat a jakým způsobem (Cothran \& Ennis, 1997). To dokládají postřehy učitelů, kteří již za sebou mají delší praxi, podle nichž jsou plány zejména u studentů učitelství precizní, nicméně v reálném světě třídy často nerealizovatelné. To může opět vyústit v mocenské uspořádání, které je svou povahou konfliktní, př́padně v němž žáci hledají únikové strategie (např. denní snění). Jedná se přitom svým způsobem o začarovaný kruh, nebot' když se žáci nudí, trpí i kvalita jejich práce, protože ji dělají mechanicky a bez rozmýšlení, čímž se pro ně přirozeně ztrácí její smysl. Žáci tak nevyhnutelně dál ztrácí zájem o výuku. Jejich cíle a cíle jejich učitelů se diverzifikují, definice situace se rozrůzňují a uspořádání ve třídě se dál vzdaluje od kooperace.

Druhým opakovaným důvodem toho, proč může být mocenské uspořádání ve třídách začínajících učitelů a stejně tak studentů učitelství problematické, lze hledat v rovině interpersonálních vztahů učitelů a žáků. Budoucí a začínající učitelé pochopitelně mohou se svými žáky vstupovat do celé palety vztahů, nicméně - jak jsme uvedly - vzhledem $\mathrm{k}$ jejich věku a pozici na startu profesní dráhy je pravděpodobnější, že se budou chtít stát spíše přátelskými učiteli (Brekelmans \& Creton, 1993, in Lukas, 2007, s. 51-52). Ačkoli se jedná o vztah, který je z hlediska dosahování kooperace ve tř́dě optimální, objevuje se právě v rámci tohoto vztahu riziko spojené s nastavením adekvátní hranice. Například Aultmanová et al. (2009, s. 364) na základě svého šetření založeném na hloubkových rozhovorech s učiteli výrazně odlišují mezi tím být přítel žáků a být přátelský a podotýkají, že identifikace demarkační linie může být na začátku praxe velmi problematická. V českém kontextu se můžeme opř́t o výzkum Šed’ové $(2011,2012)$, který dokládá, že učitelé, jejichž vyučovací hodiny vykazují personální orientaci a u nichž přitom nedojde ke shodě na definici situace s jejich žáky, jsou v zásadě učitelé začínající.

Do třetice proti studentům učitelství (opust'me zde na okamžik začínající učitele) stojí také některé z kontextuálních proměnných. Je pro ně totiž poměrně obtížné dosáhnout ve třídě autonomie v plánování výuky (srov. Ingersoll, 1996), nebot' plán výuky je jim často jednoduše předán jejich cvičným učitelem. Jejich vztah s vedením školy (srov. Cothran \& Ennis, 1997) i rodiči prozatím neexistuje a mnohdy během období praxe ani nemusí být vytvořen. To vše lze chápat jako podněty ke zvážení při koncipování pedagogických praxí studentů učitelství. 
Na druhou stranu ovšem dodejme, že období, kdy studenti učitelství a začínající učitelé vstupují do praxe, je zcela specifické právě tím, že se jedná o tzv. období hájení - právě v této fázi mohou dělat chyby, být neúspěšní (Švaříček, 2007, s. 361) a postupně najít svoji vlastní cestu, jak se vyrovnat $s$ nástrahami učitelské profese, mezi něž patří také funkční uspořádání mocenských vztahů.

\section{Literatura}

Alderman, G. L., \& Green, S. K. (2011). Social powers and effective classroom management: Enhancing teacher-student relationships. Intervention in School and Clinic, 47(39), 40-44.

Aultman, L. P., Williams-Johnson, M. R., \& Schutz, P. A. (2009). Boundary dilemmas in teacherstudent relationships: Struggling with "the line“. Teaching and Teacher Education, 25(5), 636-646.

Bendl, S. (2001). Školní kázeň: Metody a strategie. Praha: ISV.

Bendl, S. (2004). Jak předcházet nekázni, aneb kázeňské prostředky. Praha: ISV.

Bernshausen, D., \& Cunningham, C. (2001). The role of resiliency in teacher preparation and retention. Př́spěvek prezentovaný na konferenci American Association of Colleges for Teacher Education 53rd Annual Meeting, Dallas.

Bernstein, B. (1996). Pedagogy, symbolic control and identity. London: Taylor and Francis.

Bradová, J. (2013, záŕi). Teacher movement trajectories as a predictor of classroom communication processes. Př́íspěvek prezentovaný na konferenci Conference Performativity, Materiality and Time, Kodaň.

Buzzelli, C., \& Johnston, B. (2001). Authority, power, and morality in classroom discourse. Teaching and Teacher Education, 17(8), 873-884.

Cazden, C. B. (1988). Classroom discourse: The language of teaching and learning. Portsmouth: Heinemann Back.

Cothran, D. J., \& Ennis C. D. (1997). Students' and teachers' perception of conflict and power. Teaching and Teacher Education, 13(5), 541-553.

Crone, L. J., \& Teddlie, C. (1995). Further examination of teacher behavior in differentially effective schools: Selection and socialization process. Journal of Classroom Instruction, 30(1), 1-9.

Čáp, J., \& Mareš, J. (2001). Psychologie pro učitele. Praha: Portál.

Elias, S. (2007). Influence in the ivory tower: Examining the appropriate use of social power in the university classroom. Journal of Applied Social Psychology, 37(11), 2532-2548.

Elias, S. M., \& Mace, B. L. (2005). Social power in the classroom: Student power in the classroom: Student attribution for compliance. Journal of Applied Social Psychology, 35(8), 1738-1754.

Ennis, C. D. (1995). Teachers' responses to noncompliant students: The realities and consequences of a negotiated curriculum. Teaching and Teacher Education, 11(5), 445-460.

Forman, E. A., McCormick D. E., \& Donato, R. (1998). Learning what counts as a mathematical explanation. Linguistics and Education, 9(4), 313-339.

Foucault, M. (1978). The will to knowledge: The history of sexuality. London: Penguin.

French, J. R. P., \& Raven, B. (1959). The bases of social power. In D. Cartwright \& A. Zander. Group dynamics (s. 259-269). New York: Harper \& Row. 
Goffman, E. (1999). Všichni hrajeme divadlo. Praha: Nakladatelství studia Ypsilon.

Hammersley, M., \& Woods, P. (Eds). (1984). Life in school: Sociology of pupil culture. Milton Keynes: Open University Press.

Hargreaves, D. (1972). Interpersonal relations and education. Boston: Routledge and K. Paul.

Hawes Denos, C. (2003). Negotiating for positioning of power in a primary classroom. Language Arts, 80(6), 416-424.

Hilsdon, J. (1997). Nominalisation in the classroom: Issues of power and identity. International Journal of Educational Development, 17(4), 417-425.

Ingersoll, R. M. (1996). Teachers' decision-making power and school conflict. Sociology of Education, 69(2), 159-176.

Jacobs, G. E. (2012). Models of power and the deletion of participation in a classroom literacy event. Journal of Research in Reading, 35(4), 353-371.

Janík, T., Slavík, J., Mužík, V., Trna, J., Janko, T., Lokajíčková, V., ... \& Zlatníček, P. (2013). Kvalita (ve) vzdělávání. Brno: Masarykova univerzita.

Jamieson, D. W., \& Thomas, K. W. (1974). Power and conflict in the student-teacher relationship. Journal of Applied Behavioral Science, 10(3), 321-336.

Kaščák, O. (2006). Moc školy: o formatívnej sile organizácie. Trnava: Typi Universitatis Tyrnaviensis.

Kaščák, O. (2008). 0 moci školy a bezmocnosti dětí. Studia paedagogica, 13(1), 127-140.

Kearney, P., Plax, T., Richmond, \& V. P., McCroskey, J. C. (1984). Power in the classroom IV: Alternatives to discipline. In R. Bostrom (Ed.), Communication Yearbook 8 (s. 724-746), Beverly Hills: Sage.

Keller, J., \& Tvrdý, L. (2008). Vzdělanostní společnost? Chrám, výtah a pojištovna. Praha: SLON.

Kenkmann, A. (2011). Power and authenticity: Moving from the classroom to the museum. Adult Education Quarterly: A Journal of Research and Theory, 61(3), 279-295.

Kremer-Hayon, L., \& Ben-Peretz, M. (1986). Becoming a teacher: The transition from teachers' college to classroom life. International Review of Education, 32(4), 413-422.

Kučera, M. (1995). Commitment a věčné rozpory učitelského povolání. In Stát se učitelem (s. 59-94). Praha: Pedagogická fakulta Univerzity Karlovy.

Lortie, D. C. (1975). The schoolteacher. Sociological Study. Chicago: University of Chicago Press.

Lukas, J., \& Švaříček, R. (2007). Reflexe problematiky zkoumání identity učitele. Příspěvek prezentovaný na XV. konferenci České asociace pedagogického výzkumu, České Budějovice.

Lukas, J. (2007). Vývoj učitele: přehled relevantních teorií a výzkumů (1. část). Pedagogika, 57(4), 46-60.

Malach, J. (2007). Teorie metodiky výchovy. Praha: Univerzita Jana Amose Komenského.

Makovská, Z. (2011). Techniky změny chování a jejich využití ze strany žáků. Pedagogická orientace, 21(1), 85-103.

Makovská, Z. (2010). Pojetí moci v žákovských vyprávěních. Studia paedagogica, 15(2), 141-151.

Maňák, J. (2003). Nárys didaktiky. Brno: Masarykova univerzita.

Marzano, R., Marzano, J. S., \& Pickering, D. (2003). Classroom management that works: Researchbased strategies for every teacher. Alexandria: Association for Supervision and Curriculum Development.

McCroskey, J. C., Richmond, V. P., \& McCroskey, L. L. (2006). An introduction to communication in the classroom: The role of communication in teaching and training. Boston: Allyn \& Bacon. 
Merrett, F., \& Wheldall, K. (1993). How do teachers learn to manage classroom behaviour? A study of teachers' opinions about their initial training with special reference to classroom behaviour management. Educational Studies, 19(1), 91-106.

Moscovici, H. (2002) Dynamics of power in teaching college biology: Influence on students' learning. In P. C. S. Taylor, P. J. Gilmer, \& K. Tobin (Eds.), Transforming undergraduate science teaching: Social constructivist perspectives (s. 91-116). University of Pennsylvania: Lang Publishers

Moscovici, H. (2007). Mirror, mirrors on the wall, who is the most powerful of all? A self-study analysis of power relationships in science methods courses. Journal of Research in Science Teaching, 44(9), 1370-1388.

Murray, C., \& Pianta, R. (2007). The importance of teacher-student relationships for adolescents with high incidence disabilities. Theory Into Practice, 46(2) 105-112.

Novotný, P. (1997). Autoritářství jako jedna z determinant výkonu učitelské profese. Pedagogika, 47(3), 247-258.

Oyler, C. (1996). Making room for students: Sharing teacher authority in room 104. New York: Teachers College Press.

Pařízek, V. (1988). Učitel a jeho povolání. Praha: SPN.

Pravdová, B. (2013). Já jako učitelka: profesní sebepojetí studentky učitelství v posledním ročníku pregraduální přípravy. Pedagogická orientace, 23(2), 174-194.

Rigel, M. (2012). Vývoj kázeňských postihů na školách v českých zemích aneb Vyhání metla děti z pekla? Komenský, 137(2), 12-16.

Richmond, V., \& Roach, D. (1992). Power in the classroom: Seminal studies. In V. Richmond \& J. McCroskey (Eds.), Power in the classroom: Communication, control and concern (s. 47-66). New Jersey: Lawrence Erlbaum Associates.

Schrodt, P., Witt, P. L., \& Turman, P. D. (2007). Reconsidering the measurement of teacher power use in the college classroom. Communication Education, 56(3), 308-332.

Schultz, B. D., \& Oyler, C. (2006). We make this road as we walk together: Sharing teacher authority in a social action curriculum project. Curiculum Inquiry, 36(4), 423-451.

Stage, S. A., \& Quiroz, D. R. (1997). A meta-analysis of interventions to decrease disruptive classroom behavior in public education settings. School Psychology Review, 26(3), 333-368.

Staton, A. Q. (1992). Teacher and student concern and classroom power and control. In V. Richmond \& J. McCroskey (Eds.), Power in the classroom: Communication, control and concern (s. 159-176). New Jersey: Lawrence Erlbaum Associates.

Šed'ová, K. (2012). Vztahová rovina výukové komunikace: mocenské konstelace ve školní třidě. In K. Šed'ová, R. Švaříček, \& Z. Šalamounová, Komunikace ve školní trí́dě (s. 231-264). Praha: Portál.

Šed’ová, K. (2011). Mocenské konstelace ve výukové komunikaci. Studia paedagogica, 16(1), 89-118.

Švaříček, R. (2009). Narativní a sociální konstrukce profesní identity učitele experta (Disertační práce). Dostupné z https://is.muni.cz/auth/th/12302/ff_d/SVARICEK_Narativni_a_ socialni_konstrukce_profesni.pdf

Vališová, A., \& Kasíková, H. (2007). Pedagogika pro učitele. Praha: Grada.

Vališová, A. (1998). Autorita jako pedagogický problém. Praha: Karolinum.

Veenman, S. (1987). On becoming a teacher: An analysis of initial training. Příspěvek prezentovaný na konferenci Conference on Education of the World Rasque Congress, Bilbao. 
Viktorová, I. (1995). Studenti pedagogické fakulty k profesi učitele. In Stát se učitelem (s. 95-117). Praha: Pedagogická fakulta Univerzity Karlovy.

Vlčková, K., Bradová, J., \& Šalamounová, Z. (2013, září). Perceived teachers' power in the context of length of their practice. Příspěvek prezentovaný na konferenci ECER - European Conference on Educational Research, Istanbul.

Winograd, K. (2002). The negotiative dimension of teaching: Teachers sharing power with the less powerful. Teaching and Teacher Education, 18(3), 343-362.

Woods, P. (1983). Sociology and the school. An interactionist viewpoint. London: Routledge.

Wubbels, T., \& Brekelmans, M. (2005). Two decades of research on teacher-student relationships in class. International Journal of Educational Research, 43(1-2), 6-24.

Wubbels, T., Creton, H. A., \& Hooymayers, H. P. (1992). Review of research on teacher communication styles with use of the Leary model. Journal of Classroom Interaction, 27(1), $1-12$.

\section{Autorky}

Mgr. Zuzana Šalamounová, Masarykova univerzita, Pedagogická fakulta, Katedra pedagogiky, Poříčí 31,603 00 Brno, e-mail: salamounova@ped.muni.cz

Mgr. Jarmila Bradová, Masarykova univerzita, Pedagogická fakulta, Katedra pedagogiky, Porríčí 31, 60300 Brno, e-mail: bradova@ped.muni.cz

Mgr. Kateřina Lojdová, Ph.D., Masarykova univerzita, Pedagogická fakulta, Katedra pedagogiky, Poř́čí 31, 60300 Brno, e-mail: lojdova@ped.muni.cz

\section{Power relationships between novice teachers and their students}

Abstract: This theoretical study deals with a concept of power, in relation to which it follows several objectives. The purpose of the study is to analyse the concept of power through its central features and seize deeper understanding of its definition. Firstly, we define the concept of power as circular, situational and reciprocal phenomenon. Following this, we aim to introduce intervening factors, which are reflected into the form of classroom power arrangement and which may play an important role in the power arrangement in classes taught by student teachers or beginning teachers. These factors are consensus between students and their teachers, mutual relationships and context. In terms of findings, the functional setting of power relations is perceived as one of the key issues beginning teachers are confronted by when entering the profession and also becomes a key reason for them when deciding to leave the profession.

Keywords: power, conflict, consensus, cooperation, novice teachers, student teachers, reality shock 